\title{
Evaluation of Citron (Citrus medica) Accessions under North Eastern Region of Bangladesh
}

\author{
J.C. Sarker ${ }^{1 *}$, M.H.M.B. Bhuyan ${ }^{1}$ and S.M.L. Rahman ${ }^{1}$
}

Citrus Research Station, Bangladesh Agricultural Research Institute, Jaintiapur, Sylhet, Bangladesh

*Corresponding author

\section{Keywords}

Fruit, Albedo, Flevedo, Peel, Citron, Accessions

Article Info

Accepted:

20 March 2019

Available Online:

10 April 2019

\section{A B S T R A C T}

The goal of this research was to evaluate citron (Citrus medica) accessions for their vegetative and yield contributing characters for increasing productivity through superior accessions maintained at Citrus Research Station, Bangladesh Agricultural Research Institute (BARI), Jaintapur, Sylhet, Bangladesh. The experimental plot had sandy loam textured soil. Nine citron germplasm collection from farmer's field of different locations of Sylhet region of Bangladesh and were used as the planting material. Plants were planted in randomized complete block design with three replications and evaluated in 2015 on the basis of their growth, yield attributes and fruit characters viz., plant height, plant volume, time of flowering, duration from flower to fruit maturity (Days), number of fruits/plant, Individual fruit weight $(\mathrm{g})$, yield/plant $(\mathrm{kg})$, fruit yield $(\mathrm{t} / \mathrm{ha})$, yield efficiency $\left(\mathrm{kg} / \mathrm{m}^{3}\right)$, fruit length $(\mathrm{cm})$, fruit diameter $(\mathrm{cm})$, Peel thickness $(\mathrm{mm})$, Peel weight $(\mathrm{g})$, Albedo TSS $(\%)$, number segments/fruit, seed weight/fruit $(\mathrm{g})$, edible portion $(\%)$ along with some qualitative traits like fruit surface texture, fruit axis, fruit shape, fruit apex, fruit base, flavedo color, albedo color, fruit aroma. The results showed that the growth parameters differed significantly among the tested accessions. Highest number (41.7) of fruits per plant, largest fruits $(8312 \mathrm{~g})$, highest yield/plant $(34.85 \mathrm{~kg})$ and highest yield/ha $(21.78 \mathrm{t})$ were recorded in CM Jai-062. Beside this CM Jai -061, CM Jai -063 and CM Jai -064 also had higher yield capability.

\section{Introduction}

The genus Citrus, belonging to the Rutaceae or Rue family, comprises of about 140 genera and 1,300 species. Citrus sinensis (Sweet Orange), Citrus paradise (Grapefruit), Citrus limon (Lemon), Citrus reticulata (Mandarin), Citrus grandis (Pummelo), Citrus aurantium (sour orange), Citrus medica (Citron), and Citrus aurantifolia (lime) are some important species of genus Citrus (Kamal et al., 2011). Scora (1975) and Barrett and Rhodes (1976) suggested that there are only three 'basic' true species of citrus within the subgenus Citrus as follows: citron (Citrus medica L.), mandarin (C. reticulata Blanco), and pummelo (Citrus maxima (Burm) Merrill), other species within this subgenus are hybrids derived from these true species, species of subgenus Papeda or closely related genera. The natural and 
commercially cultivated citrus include oranges, grapefruits, lemons, lime and citron.

Citron is a fragrant citrus fruit, botanically named as Citrus medica. The designation medica given by Linnaeus is apparently derived from its ancient name "Median or Persian apple" that was reported by Theophrastus, who believed it to be native to Persia or the land of the Medes.

The edible fruit of various citrus species are widely used for flavors, jam, pickles and confectioneries. Essential oils obtained from the leaves and fruit are also used as perfumery ingredient to scent toiletry products. Widely known as citron, the hybrids and cultivars of C. medica is often grown or cultivated for their fruit production mainly for medicinal and ritual purposes rather than for food (Morton, 1987). Various parts of the plant have been used in traditional medicinal preparations for the treatment of asthma, arthritis and stomachache (Perry, 1980).

The lemon and orange are peeled to consume their pulpy and juicy segments but the citron's pulp is dry, containing a small quantity of insipid juice. The main content of a citron fruit is the thick white peel, which adheres to the segments, and cannot be separated easily. This peel is eaten with rice in Bangladesh, India and Indonesia as fresh or salad like cucumber or tomato. As fresh or salad it differs with cucumber or tomato in terms of eating system, i.e., it must be eaten just after rice like as queen chilli. This fruit is weighted from $250 \mathrm{~g}$ to $3.5 \mathrm{~kg}$ or more. But the exportable size is limited to 500-600 g. Citron is now exported to the EU markets from Bangladesh. As Bangladesh is one of the primary centers of origin of citron.

Citron peel is eaten with rice in Bangladesh, India and Indonesia. In Spain, syrup made from the peel is used to flavor unpalatable medical preparations, and in Guatemala, it is used as flavoring for soft drinks (Bhuiyan et al., 2009). In Brazil, the peel is used to prepare jellies and other sweets (preserves and crystallized fruit). This species is also used for the treatment of various diseases in traditional Indian medicine. The ripe fruit is used to treat sore throat, cough, asthma, earache, scurvy and hemorrhoids. The water distilled from the fruit is soothing (Kirtikar and Basu, 1993; API, 2001). The seeds are used as a vermifuge, a stimulant and a cardiac tonic. In China and Japan, the fruit is used as an air freshener and is considered a symbol of happiness and prosperity.

The north-eastern region is rich treasure of various Citrus species and varieties (Bhattacharya and Dutta, 1956). Northeastern region of Bangladesh is major citrus producing area, accounting for more than 60 $\%$ of citrus production in the region (Anon., 2010). Citron is grown successfully in this region is gaining importance because of export potentiality worldwide for its aroma and nutritive value. The average yield of citron in Bangladesh relatively low compared to that of other citron producing countries. Among citrus, citron is considered as the most important horticultural fruit crop of the regions, which plays vital role in sustaining the livelihood of farmers. This is due to presence of vast diversity among accessions in horticultural traits, thus lack of high yield variety maybe minimized by detailed and systematic study. Therefore, the objective of this work was to evaluate citron accessions for their vegetative and yield contributing characters for increasing productivity through superior accessions.

\section{Materials and Methods}

\section{Field plot management}

The experiment was set up at Citrus Research Station, Bangladesh Agricultural Research 
Institute (BARI), Jaintapur, Sylhet $\left(25.13562^{\circ}\right.$ $\mathrm{N}$ latitude, $92.13217^{\circ} \mathrm{E}$ longitude, $36 \mathrm{~m}$ of elevation from mean sea level), Bangladesh, during 2015. A total of nine citron germplasm were used for the study. The plants were planted in square planting system with $4 \times 4 \mathrm{~m}^{2}$ spacing in the year of 2005. The climatic condition of the experimental location was subtropical in nature, which is characterized with the pre monsoon (March to April), the monsoon (May to September) and the winter or dry season (November to February). Annual average rainfall ranges from 4500$6000 \mathrm{~mm}$, the mean maximum and minimum temperatures are $36^{\circ} \mathrm{C}$ and $6^{\circ} \mathrm{C}$ in the month of April and January respectively (Table 1).

The soil of the experimental plot belongs to northern and eastern piedmont plains (AEZ 22 of Bangladesh) having sandy loam textured soil [9]. At the very beginning of the study the soil was with $\mathrm{pH} 4.8$ and organic carbon 1.28 per cent. Each plant was fertilized with $7 \mathrm{~kg}$ cow dung, $200 \mathrm{~g}$ of urea, $150 \mathrm{~g}$ of TSP and $200 \mathrm{~g}$ of MoP in two equal splits one before rainy season and another after rainy season. Two full cover spray of cupravit@7.0 g/l was applied 3-4 times at 10-12 days intervals to control canker disease. Imidachloprid (Imitaf @ $0.25 \mathrm{ml} / \mathrm{L}$ ) was applied to control leaf miner when new leaves emerged. Weeding was done in rainy season before applying fertilizer.

\section{Measurements}

Data were recorded on growth parameters viz. growth in plant height, canopy spreading, plant volume $\left(\mathrm{m}^{3}\right)$, fruits per plant, yield per plant $(\mathrm{kg})$ and yield efficiency $\mathrm{kg}$ per plant per $\mathrm{m}^{3}$. Following (Wutscher and Hill, 1995) through minor amendment canopy volume were calculated via the formula $\mathrm{V}\left(\mathrm{m}^{3}\right)=(\mathrm{H} \times$ $\left.\mathrm{D}^{2}\right) / 4$ where, $\mathrm{V}$ was plant volume, $\mathrm{H}$ was plant height and D was the average value of north-south and east-west spreading of the canopy. Yield (kg/plant) was recorded on every commercial harvest. Yield efficiency was calculated as the ratio of fruit yield (kg/plant) to canopy volume $\left(\mathrm{m}^{3}\right)$. The relationship between yield efficiency and tree volume was analyzed by a regression model (Cantuarias, 2010). Data on growth and fruit characters were recorded as per the descriptor for Citrus (IPGRI, 1999).

\section{Experimental design and statistical analysis}

The experiment arranged in a completely randomized block design (RCBD) with three replications and each replication had 10 plants. Data were analyzed using MSTATC and means were compared by Duncan's multiple range test (DMRT) at $5 \%$ level of confidence.

\section{Results and Discussion}

A wide variation was observed in case of different growth characteristics of the citron germplasm tested. Size of canopy (plant height and volume) is positively related with fruit yield of citrus (Anderson, 1987; Obreza and Rouse, 1993). Maximum plant height was recorded in CM Jai-060 (2.88 m) which was statistically similar with CM Jai-064 (2.79 m), CM Jai-062(2.75m) and CM Jai-065(2.74m) while minimum $(2.06 \mathrm{~m})$ was found in $\mathrm{CM}$ Jai-067 (Figure 1).

Plant volume is an important parameter for determining the spacing of the plant. Hence plant volume is measured and found significant variation among different genotypes tested. Overall average plant volume varied from $5.16 \mathrm{~m}^{3}$ to $3.02 \mathrm{~m}^{3}$. In the study more vigorosity $\left(5.16 \mathrm{~m}^{3}\right)$ was found in CM Jai-062 followed by CM Jai-060 (5.02 $\left.\mathrm{m}^{3}\right)$ While comparatively weak plants $(3.02$ $\mathrm{m}^{3}$ ) was found in CM Jai-067 (Figure 2). 
Time of flowering is one the most important reproductive characters regarding yield. The earliness of flowering confirms earlier yield that can benefit a farmer easily. The flowering time varied from February to March (Table 2), however, CM Jai-059, CM Jai-062 and CM Jai-065 showed precocious flowering, whereas, CM Jai-060, CM Jai-061, CM Jai063, CM Jai-064, CM Jai-066 and CM Jai067 were late in flowering.

Harvest duration plays an important role in farmer's point of view because longer harvest duration can benefit farmers a lot. CM Jai-062 had the shortest fruit development cycle and got matured in 118.7 days whereas, CM Jai067 had the longest fruit development period of 138.7 days.

Highest number of fruits was recorded in $\mathrm{CM}$ Jai-062 (41.67) while lowest in CM Jai-067 (17.33). Maximum yield per plant $(34.85 \mathrm{~kg})$ was recorded in CM Jai-062 whereas lowest in CM Jai-067 (11.11 kg).

A very highly significant variation was observed on fruit yield. The fruit yield varied from 6.94 to $21.78 \mathrm{t} / \mathrm{ha}$. Maximum yield per hectare (21.78 t/ha) was recorded in CM Jai062 which was statistically different from other accessions. On the other hand, the minimum fruit yield (6.94 t/ha) was found from CM Jai-067 (Figure 3).

Variation was also found in respect of quantitative fruit characters also (Table 3). Physical properties of fruits of different accessions clearly indicate that CM Jai-062 bear relatively bigger and heavier fruits, whereas CM Jai-060 has the smallest and lightest fruits.

The peel is an important factor for the quality of citron fruit. Peel thickness varied marginally with accessions and the maximum peel thickness $(27.13 \mathrm{~mm})$ was recorded in CM Jai-062 followed by CM Jai-066 (25.13mm) whereas minimum in CM Jai-060 $(15.07 \mathrm{~mm})$.

The chemical analysis of fruit showed that CM Jai-062 had the highest albedo TSS (6.9\%) followed by CM Jai-060 (6.6\%) while lowest in CM Jai-059 (2.2\%). CM Jai-062 had the maximum number of segments, whereas CM Jai-065 had the minimum.

Table.1 Weather data for the experimental period

\begin{tabular}{|l|c|c|c|c|}
\hline \multirow{2}{*}{ Month } & \multicolumn{2}{|c|}{ Temperature $^{\mathbf{0}} \mathbf{C}$} & $\begin{array}{c}\text { Precipitation } \\
(\mathbf{m m})\end{array}$ & $\begin{array}{c}\text { Relative humidity } \\
(\mathbf{\%})\end{array}$ \\
\cline { 2 - 3 } January' 2015 & Maximum & Minimum & 2 & 74 \\
\hline February' 2015 & 33.3 & 15.7 & 9 & 69 \\
\hline March' 2015 & 33.1 & 9.1 & 21 & 72 \\
\hline April' 2015 & 26.3 & 9.8 & 6 & 61 \\
\hline May' 2015 & 28.4 & 12.7 & 8 & 64 \\
\hline June' 2015 & 32.2 & 14.4 & 55 & 67 \\
\hline July' 2015 & 33.1 & 20.1 & 265 & 69 \\
\hline August' 2015 & 33.5 & 21.5 & 1023 & 78 \\
\hline September' 2015 & 36.1 & 24.1 & 987 & 56 \\
\hline October' 2015 & 27.5 & 23.1 & 47 & 57 \\
\hline November' 2015 & 29.2 & 19.2 & 11 & 64 \\
\hline December' 2015 & 26.9 & 14.7 & 4 & 75 \\
\hline
\end{tabular}


Table.2 Yield and yield contributing characters of Citron accessions

\begin{tabular}{|c|c|c|c|c|}
\hline accessions & Time of Flowering & $\begin{array}{l}\text { Duration from } \\
\text { Flower to fruit } \\
\text { maturity (Days) }\end{array}$ & $\begin{array}{l}\text { Number of } \\
\text { fruits/plant }\end{array}$ & $\begin{array}{c}\text { Weight of } \\
\text { fruits/plant } \\
\text { (kg) }\end{array}$ \\
\hline CM Jai-059 & Feb. $1^{\text {st }}$ fortnight & $128.3 b c$ & $26.00 \mathrm{e}$ & 12.49 ef \\
\hline CM Jai-060 & Mar. $1^{\text {st }}$ fortnight & $129.3 b$ & $31.33 \mathrm{~d}$ & $12.62 \mathrm{de}$ \\
\hline CM Jai-061 & Feb. $2^{\text {st }}$ fortnight & $128.3 b c$ & $24.67 \mathrm{e}$ & $14.01 \mathrm{~d}$ \\
\hline CM Jai-062 & Feb. $1^{\text {st }}$ fortnight & $118.7 d$ & $41.67 \mathrm{a}$ & $34.85 \mathrm{a}$ \\
\hline CM Jai-063 & Mar. $1^{\text {st }}$ fortnight & $123.3 \mathrm{~cd}$ & $33.67 \mathrm{c}$ & $17.39 \mathrm{c}$ \\
\hline CM Jai-064 & Feb. $2^{\text {st }}$ fortnight & $132.3 b$ & $35.67 \mathrm{~b}$ & $22.49 b$ \\
\hline CM Jai-065 & Feb. $1^{\text {st }}$ fortnight & $133.7 b$ & $18.00 \mathrm{~g}$ & $13.28 \mathrm{de}$ \\
\hline CM Jai-066 & Feb. $1^{\text {st }}$ fortnight & $128.3 b c$ & $22.67 \mathrm{f}$ & $18.31 \mathrm{c}$ \\
\hline CM Jai-067 & Feb. $2^{\text {st }}$ fortnight & $138.7 \mathrm{a}$ & $17.33 \mathrm{~g}$ & $11.11 \mathrm{f}$ \\
\hline LSD & - & 4.96 & 1.40 & 1.38 \\
\hline $\mathrm{CV} \%$ & - & 2.22 & 2.90 & 4.59 \\
\hline
\end{tabular}

Table.3 Quantitative fruit characteristics of Citron accessions

\begin{tabular}{|c|c|c|c|c|c|c|c|c|c|}
\hline \multirow[t]{2}{*}{ Accessions } & \multirow{2}{*}{$\begin{array}{c}\text { Individual } \\
\text { fruit } \\
\text { weight } \\
\text { (g) }\end{array}$} & \multicolumn{2}{|c|}{ Fruit size $(\mathbf{c m})$} & \multirow{2}{*}{$\begin{array}{c}\text { Peel } \\
\text { thickness } \\
(\mathbf{m m})\end{array}$} & \multirow{2}{*}{$\begin{array}{c}\text { Peel } \\
\text { weight } \\
\text { (g) }\end{array}$} & \multirow{2}{*}{$\begin{array}{l}\text { Albedo } \\
\text { TSS } \\
(\%)\end{array}$} & \multirow{2}{*}{$\begin{array}{l}\text { Segments/ } \\
\text { fruit (No.) }\end{array}$} & \multirow{2}{*}{$\begin{array}{c}\text { Seed } \\
\text { weight/ } \\
\text { fruit } \\
\text { (g) }\end{array}$} & \multirow{2}{*}{$\begin{array}{c}\text { Edible } \\
\text { portion } \\
(\%)\end{array}$} \\
\hline & & Length & Diameter & & & & & & \\
\hline CM Jai-059 & $480.3 \mathrm{~d}$ & $16.5 \mathrm{~b}$ & $7.4 \mathrm{e}$ & $18.07 \mathrm{f}$ & $340.7 \mathrm{~g}$ & $2.2 \mathrm{~g}$ & $12 \mathrm{abc}$ & $2.2 \mathrm{~g}$ & $70.53 \mathrm{c}$ \\
\hline CM Jai-060 & $291.6 \mathrm{e}$ & $10.7 \mathrm{~g}$ & $9.2 \mathrm{~d}$ & $15.07 \mathrm{~h}$ & $300.2 \mathrm{~h}$ & $6.6 \mathrm{~b}$ & $11 \mathrm{bc}$ & $5.6 \mathrm{f}$ & $70.30 \mathrm{c}$ \\
\hline CM Jai-061 & $559.8 \mathrm{~cd}$ & $13.5 \mathrm{de}$ & $9.7 \mathrm{c}$ & $19.10 \mathrm{e}$ & $395.8 \mathrm{e}$ & $5.2 \mathrm{e}$ & $12 a b c$ & $12.5 \mathrm{e}$ & $70.79 \mathrm{bc}$ \\
\hline CM Jai-062 & $831.2 \mathrm{a}$ & $18.4 \mathrm{a}$ & $10.5 \mathrm{a}$ & $27.13 \mathrm{a}$ & $661.8 \mathrm{a}$ & $6.9 \mathrm{a}$ & $14 \mathrm{a}$ & $24.9 \mathrm{a}$ & $79.43 \mathrm{a}$ \\
\hline CM Jai-063 & $511.3 \mathrm{~cd}$ & $12.3 \mathrm{f}$ & $9.2 \mathrm{~d}$ & $20.03 \mathrm{~d}$ & $340.6 \mathrm{~g}$ & $5.6 \mathrm{~d}$ & $12 a b c$ & $21.1 \mathrm{~b}$ & $66.46 \mathrm{~d}$ \\
\hline CM Jai-064 & $627.2 \mathrm{bcd}$ & $13.1 \mathrm{ef}$ & $10.4 \mathrm{a}$ & $19.23 \mathrm{e}$ & $365.1 \mathrm{f}$ & $4.5 \mathrm{f}$ & $13 \mathrm{ab}$ & $19.1 \mathrm{c}$ & $58.77 \mathrm{e}$ \\
\hline CM Jai-065 & $735.2 \mathrm{ab}$ & $14.6 \mathrm{~cd}$ & $9.9 \mathrm{~b}$ & $23.17 \mathrm{c}$ & $536.6 \mathrm{c}$ & $4.7 \mathrm{f}$ & $10 \mathrm{c}$ & $22.2 b$ & $72.54 \mathrm{~b}$ \\
\hline CM Jai-066 & $797.5 \mathrm{a}$ & $15.3 \mathrm{c}$ & $10.3 \mathrm{a}$ & $25.13 \mathrm{~b}$ & $621.6 \mathrm{~b}$ & $5.7 \mathrm{~d}$ & $13 \mathrm{ab}$ & $24.3 \mathrm{a}$ & $78.35 \mathrm{a}$ \\
\hline CM Jai-067 & $647.2 \mathrm{bc}$ & 12.9 ef & $9.8 \mathrm{bc}$ & $16.90 \mathrm{~g}$ & $465.9 \mathrm{~d}$ & $6.2 \mathrm{c}$ & $12 a b c$ & $17.2 \mathrm{~d}$ & $71.71 \mathrm{bc}$ \\
\hline LSD & 139.1 & 1.09 & 0.19 & 0.70 & 6.56 & 0.30 & 1.86 & 1.59 & 1.72 \\
\hline $\mathrm{CV} \%$ & 13.19 & 4.46 & 1.19 & 1.98 & 0.85 & 3.33 & 8.66 & 5.53 & 1.40 \\
\hline
\end{tabular}


Table.4 Qualitative fruit characteristics of Citron accessions

\begin{tabular}{|l|c|c|c|c|c|c|c|}
\hline Accessions & $\begin{array}{c}\text { Fruit } \\
\text { surface } \\
\text { texture }\end{array}$ & $\begin{array}{c}\text { Fruit } \\
\text { Axis }\end{array}$ & $\begin{array}{c}\text { Fruit } \\
\text { Shape }\end{array}$ & Fruit Base & $\begin{array}{c}\text { Fruit } \\
\text { apex }\end{array}$ & $\begin{array}{c}\text { Flavedo } \\
\text { Color }\end{array}$ & Albedo Color \\
\hline CM Jai-059 & Rough & Solid & Ellipsoid & Truncate & Mammiform & $\begin{array}{c}\text { Greenish } \\
\text { Yellow }\end{array}$ & Creamish \\
\hline CM Jai-060 & Smooth & Hollow & Spheroid & Concave & Acute & $\begin{array}{c}\text { Greenish } \\
\text { Yellow }\end{array}$ & White \\
\hline CM Jai-061 & Smooth & Solid & Spheroid & Truncate & Mammiform & Green & White \\
\hline CM Jai-062 & Rough & Hollow & Ellipsoid & Concave & Acute & Green & Creamish \\
\hline CM Jai-063 & Rough & Hollow & Spheroid & Concave & Mammiform & $\begin{array}{c}\text { Greenish } \\
\text { Yellow }\end{array}$ & White \\
\hline CM Jai-064 & Smooth & Hollow & Ellipsoid & Truncate & Mammiform & Green & Creamish \\
\hline CM Jai-065 & Smooth & Solid & Ellipsoid & Concave & Acute & Green & White \\
\hline CM Jai-066 & Rough & Hollow & Spheroid & Truncate & Mammiform & $\begin{array}{c}\text { Greenish } \\
\text { Yellow }\end{array}$ & White \\
\hline CM Jai-067 & Smooth & Solid & Ellipsoid & Concave & Mammiform & $\begin{array}{c}\text { Greenish } \\
\text { Yellow }\end{array}$ & White \\
\hline
\end{tabular}

Fig.1 Variation in plant height (m) of different citron accessions

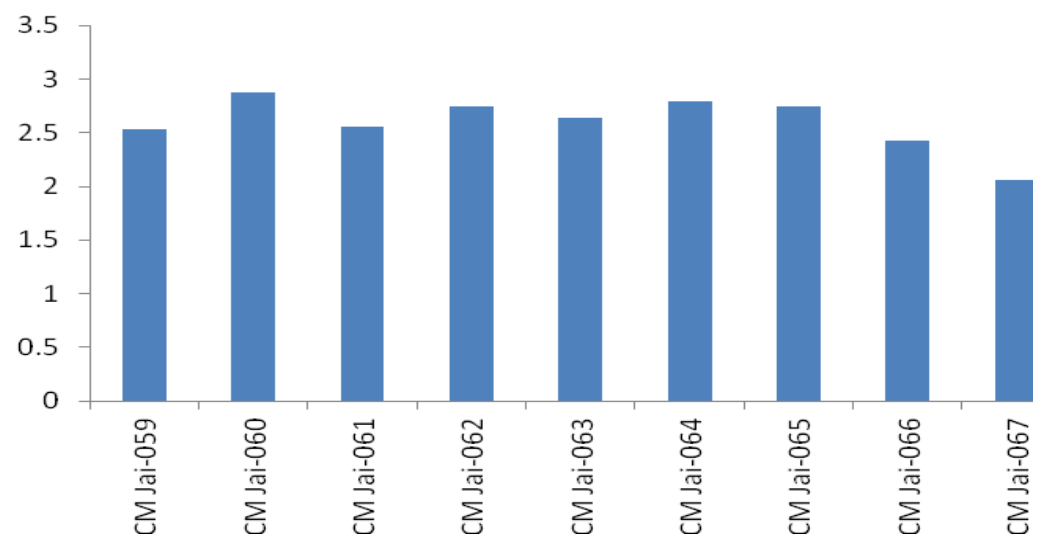

Fig.2 Variation in plant volume $\left(\mathrm{m}^{3}\right)$ of different citron accessions

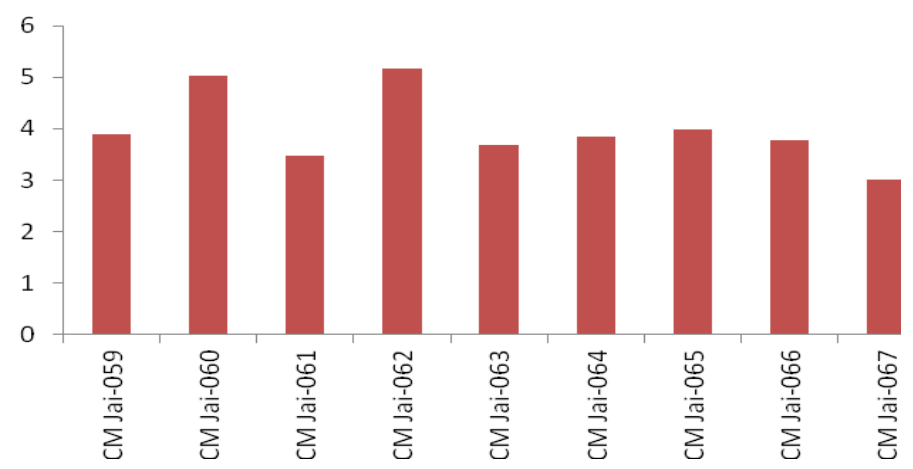


Fig.3 Variation in yield ( $\mathrm{t} / \mathrm{ha}$ ) of different tested citron accessions

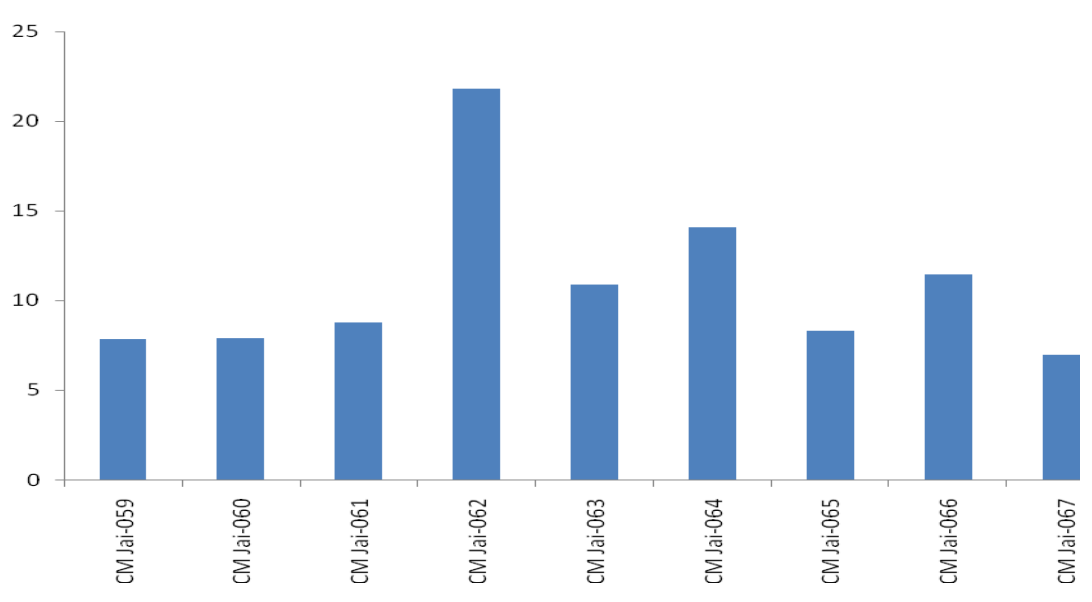

Among the accessions, CM Jai-062 was recorded with significantly highest seed weight per fruit $(24.9 \mathrm{~g})$ followed by CM Jai-066 (24.3g), CM Jai-065 (22.2g) and CM Jai-063 $(21.1 \mathrm{~g})$ while, the lowest seed weight per fruit $(2.2 \mathrm{~g})$ was found in CM Jai-059.

Maximum edible portion was recorded in $\mathrm{CM}$ Jai-062 (79.43\%) followed by CM Jai-066 (78.35\%), CM Jai-065 (72.54\%) and CM Jai$067(71.71 \%)$ while minimum in CM Jai-064 $(58.77 \%)$.

Qualitative fruit characters of different citron accessions also showed remarkable variation. Fruit surface texture is considered important variables for citron characterization. In case of fruit surface texture and fruit axis all the accessions were found rough to smooth, hollow to solid.

The shape of the fruit also showed variation. Most of the accessions had Ellipsoid fruit shape with concave fruit base and mammiform fruit apex, however, rest of the accessions had Spheroid fruit shape with truncate fruit base and acute fruit apex.

Flavedo colour of accessions varied from Greenish Yellow to green colour whereas, albedo colour of accessions varied from creamish to white. The qualitative fruit characters are as shown below in Table 4.

Preliminary evaluation studies clearly indicated that CM Jai-062 has potential in terms of fruit weight, yield/plant, yield/ha, TSS and edible portion. Beside this CM Jai -061, CM Jai -063 and CM Jai -064 also had higher yield. Therefore, it can be concluded that citron cultivation can be promoted by using these accessions under north eastern region of Bangladesh.

\section{References}

Adams RP. Identification of essential oil components by gas chromatography/ mass spectroscopy. Carol Stream, IL: Allured Publ. Corp; 2007; viii +804 .

Anderson, C.A. Fruit yields, tree size, and mineral nutrition relationships in 'Valencia' orange trees as affected by liming. Journal of Plant Nutrition, v.10, p.1907-1917, 1987.

Anonymous (2010) International Information. http://www. lona.co.za/pdf/internation information-2010.pdf

Bairagi GB, Kabra AO, Mandade RJ. Anthelmintic activity of Citrus medica L. leaves in Indian adult earthworm. Int J Pharm Tech Res 2011; 3:664-667.

Barrett, H.C., Rhodes, A.M., 1976. A numerical taxonomic study of affinity relationship 
in cultivated Citrus and its closed relatives. Syst. Bot. 1, 105-136.

Bhuiyan MNI, Begum J, Sardar PK, Rahman MS. Constituents of peel and leaf essential oils of Citrus medica L. J Sci Res 2009; 1:387-392.

Cantuarias-Avilés T, Mourão Filho FAA, Stuchi ES, Silva SR, Espinoza-Nunez E. Tree performance and fruit yield and quality of 'Okitsu' Satsuma mandarin grafted on 12 rootstocks. Scientia Horticulture. 2010; 123: 318-322.

Federici, C. T., Fang, D. Q., Scora, R. W. and Roose, M. L. (1998). Phylogenetic relationships within the genus Citrus (Rutaceae) and related genera as revealed by RFLP and RAPD analysis. TAG Theoretical and Applied Genetics 96(6): 812-822.

Gomez, K.A., A.A. Gomez. 1984. Statistical procedures for agricultural research, 2nd ed. New York: John Wiley and Sons.

Hore DK, S Govind and IP Singh (1997) Collecting of citrus germplasm from the Mizoram and Tripura hills of India. Plant Genet. Resour. Newslet. (IPGRI/FAO) 110: 57-59.

IPGRI (1999) Descriptors for Citrus. International Plant Genetic Resources Institute, Rome, Italy.

Kamal GM, Anwar F, Hussain AI, Sarri N, Ashraf MY. 2011. Yield and chemical composition of Citrus essential oils as affected by drying pretreatment of peels. Inter Food Res J. 18(4): 1275-1282.

Kirtikar KR, Basu BD. Indian medicinal plants. Dehra Dun: Pal Singh; 1993.

Malik SK, R Chaudhury, OP Dhariwal and R K Kalia (2006) Collection and characterization of Citrus indica Tanaka and $C$. macroptera Montr. wild endangered species of northeastern India. Genet. Resour. Crop Evol. 53: 1485-93.

Morton, J. (1987). Citron In: Fruits of Warm Climates. Julia F. Morton, Miami Florida, p. 179-182.

NHB (2008-09) Indian Horticulture Data Base. pp 54-79. National Horticulture Board, Ministry of Agriculture, Govt. of India, Gurgaon, Haryana.

Obreza, T.A., Rouse, R.E. Fertilizer effects on early growth and yield of 'Hamlin' orange trees. HortScience, v.28, p.111114, 1993.

Perry, L. M. (1980). Medicinal Plants of East and Southeast Asia: Attributed Properties and Uses. The Massachusetts Institute of Technology Press, Cambridge, p. 362-363.

Scora, R.W., 1975. On the history and origin of Citrus. Bull. Torrey Bot. Club 102, 369375.

Singh IP, S Singh, K Singh and R Srivastava (2001) Exploration and collection of citrus germplasm from NEH region (Meghalaya) of India. Indian J. Plant Genet. Resour. 14: 70-73.

The ayurvedic pharmacopoeia of India Part I, v. III. New Delhi: Govt of India; 2001.

Syvertsen, J.P., Lloyd, J. Citrus. In: Schaffer, B., Andersen, P. (Ed.). Handbook of environmental physiology of fruit crops. Boca Raton: CRC Press, 1994. 2: 65-99.

Vekiari SA, Protopapadakis EE, Papadopoulou P. 2002. Gas chromatography-mass spectroscopy

Wutscher, H.K., Hill, L.L., 1995. Performance of 'Hamlin' orange on 16 rootstocks in East-central Florida. HortScience 30, $41-43$.

\section{How to cite this article:}

Sarker, J.C., M.H.M.B. Bhuyan and Rahman, S.M.L. 2019. Evaluation of Citron (Citrus medica) Accessions under North Eastern Region of Bangladesh. Int.J.Curr.Microbiol.App.Sci. 8(04): 28912898. doi: https://doi.org/10.20546/ijcmas.2019.804.338 